\title{
Assessing the Priority Area of Mountainous Tourism Using Geospatial Approach in Kendal Regency, Central Java
}

\author{
Riwayatiningsih ${ }^{2, *}$ and Hartuti Purnaweni ${ }^{1,2}$ \\ ${ }^{1}$ Doctoral Program of Environmental Science, School of Postgraduate Studies, Diponegoro University, Semarang - Indonesia \\ ${ }^{2}$ Master Program of Environmental Science, School of Postgraduate Studies, Diponegoro University, Semarang - Indonesia
}

\begin{abstract}
Kendal is one of 35 regencies in Central Java which has diverse topographies, from low land, hilly, to mountainous areas. Mountainous area of Kendal with numerous unique and distinct natural environments, supported by various unique and distinct culture of its community can be used for tourism activities. Kendal has natural and sociocultural resources for developing tourism that must be considered by the local government. Therefore, nature based tourism resources assessment is important in order to determine the appropriate area in the planning of sustainable tourism destination. The objectives of this study are to assess and prioritize the potential area of mountainous tourism object in Kendal using geospatial approach based on criteria attractiveness, accessibility and amenity of the tourism object. Those criteria are modification of ADO-ODTWA guidelines and condition of the study location. There are 16 locations of tourism object that will be assessed. The result will be processed using ArcMap 10.3. The result will show the most potential tourism object that could become priority for mountainous tourism development in Kendal.
\end{abstract}

\section{Introduction}

Kendal is one of 35 regencies in Central Java which has diverse topographies, from low land, hilly to mountainous areas. Low land area is located in the northern area with altitude between 0 up to 10 meters above sea level and temperature ranges around $27^{\circ} \mathrm{C}$. The hills are in the middle area, and the mountainous area are located in the most southern area with elevations up to 2.579 meters above sea level and temperature ranges around $25^{\circ} \mathrm{C}$. [1]

The area of Kendal regency presents numerous unique and distinct natural environment, supported by various unique and distinct culture of its community which could become tourism potency to attract visitors. However, many of these areas have not been well managed, despite the potencies found such as in Gonoharjo and Curugsewu rainfall, both are located in mountainous area $[2,3]$

As a key factor in revenue, job creation, business and infrastructure development, tourism sector needs good planning to develop it. This tourism planning should not affect in environmental damage but instead must be planned and implemented to support sustainable development. [4-5]

Today, there is a growing demand for nature based tourism which becomes a new trend in the tourism industry. It was seen from a lot of documentation uploaded in social media used as self-actualization. This condition requires tourism actors, including in mountainous tourism area of Kendal Regency.

In order to develop the tourism potencies, a proper strategy is needed to manage them. By using ADOODTWA (Operational Area Analysis-Nature based
Tourism Object and Attraction) Guidelines issued by the Directorate General of Forest Protection and Nature Conservation [6] Oktadiyani, et.al [7] analyzed the Kamojang Crater Nature Park of Bandung Regency, West Java Province using several criterias including attractiveness, relationship level, lodging condition, supporting facilities and infrastructure, clean water availability, and connection with other tourism objects. While another study held in Tanjung Belandang Beaches of Ketapang Regency used criteria of attractiveness, accessibility, socio-economic conditions, accommodation, supporting facilities and infrastructure, as well as clean water availability to assess the attractiveness and development of Tanjung Belandang beaches [8].

There was also another research conducted by Bunruamkaew and Murayama [9] which was aimed to identify and prioritize the potencies of ecotourism in Surat Thani Province, Thailand using GIS and AHP. Meanwhile Rahayuningsih, et.al [4] aimed to develop spatial model of natural tourism planning based on attraction criteria and accessibility of tourism object in Bogor.

Hai-ling [10] concluded that there was a power in integrating GIS for ecotourism applications. GIS is a useful tool to solve some semi-structured spatial decision problems that is encountered in the real world. To assess the effectiveness of this application, survey can be conducted in the future to evaluate whether the system improves the experience of ecotourism tourist. This study implies that the key process can be a resource and reference for other ecosystem services analysis.

Utilizing Geographic Information System (GIS) technology as geospatial approach, it is expected that 
analysis on the spatial aspects of the mountainous area of Kendal Regency can be done, therefore the existing tourism potencies can be optimally developed into object and tourism attraction.

This article contains result of a preliminary study using 2016 data from the Youth, Sports and Tourism Office of Kendal Regency, and analysis of the 2016 data using geospatial approach

\section{Literature review}

\subsection{Tourism}

Tourism is a prime sector that is one of the most important factors in the regional development and the community welfare improvement in a country, which has continuous expansion and diversification and become one of the largest growth sectors in the world.

Tourism is a variety of travel activities supported by various facilities and services provided by the community, industrialists, and government [11]. Marpaung [12] defined tourism as human temporary transfers in order to getting out from their home and routine jobs. While tourist is everyone who travels and settles for a while in a place that is not his/ her residence for any particular reason except looking for a job.

\subsection{Tourism potency}

Tourism potency is everything that is owned by a tourist attraction and useful for developing the tourism industry in that area [13]. There are three tourism potencies in this research, i.e. nature potency, culture potency and man-made potency. Based on these three kinds of tourism potencies, tourism object also divided into three, i.e. nature based tourism, culture based tourism and manmade based tourism.

In the Operational Area Analysis Nature Based Tourism Object and Attraction (ADO-ODTWA) guidelines[6], nature based tourism is defined as a travel activity or part of voluntary and temporary activity to enjoy the symptoms uniqueness and natural beauty of natural attraction, people's forest park and nature parks. Mountainous tourism is one of nature based tourism since the tourist object is nature, beauty and phenomenal.

\subsection{Geospatial approach}

Geospatial approach is another term of Geographic Information System (GIS) that is an integration between hardware, software, human data (brain ware) which cooperate in processing data starting from data management, manipulation and data analysis so as to produce output or final result that can be used as a reference in decision making to a problem $[14,15,16]$.

GIS technology integrates common database operations, such as query and statistical analysis with maps. GIS manages location-based information and provides tools for the display and analysis of various statistics, including population characteristics, economic development opportunities, and vegetation types.

GIS allows users to connect between databases and maps to create a dynamic view. In addition, GIS also provides tools for displaying, querying, and uploading such databases in ways that traditional spreadsheets may not. This capability differentiates GIS from other information systems, and makes it valuable for government, public and private companies to explain events, predict outcomes, and planning strategies implementation.

Purnaweni [17] concluded that GIS is believed to be an important step towards more efficient and effective public policy making by an innovative government eventhough not all necessary data for formulating, planning and evaluating public policies can be provided by GIS.

\subsection{ADO-ODTWA}

Natural resources such as volcanoes, waterfalls, hot springs, craters, rivers, caves, lakes, coral reefs, and mangrove forests, are the potential objects and natural tourist attraction (ODTWA) that need serious handling in order to maintain its sustainability and existence [6].

Furthermore, the development of ODTWA requires criteria and indicators through determination of criteria elements, weighting, each sub elements calculation and the sum of all criteria element values. The objective is to determine the priority scale of ODTWA development and to intensify the utilization and development of an ODTWA.

Criteria of ODTWA assessment was issued by the Directorate General of Forest Protection and Nature Conservation in 2003, consists of attractiveness, market potency, accessibility, condition of area, visitor services, climate, accommodation, supporting facilities and infrastructure, clean water availability, connection with other tourism objects, safeness, etc. [6]

The criterias of ADO-ODTWA assessment used in this study were modified from ADO-ODTWA guidelines and Strategic Plan of The Indonesian Tourism Ministry 2015-2019. The assessment criterias are as follow 
Table 1. Assessment criteria of nature based tourism in Kendal Regency, a modification of Rahayuningsih, Tri et.al [4], ADOODTWA Guidelines [6] and Strategic Plan of Indonesian Tourism Ministry [18]

\begin{tabular}{|c|c|c|c|}
\hline No & Criteria & Elements & Sub elements \\
\hline \multirow[t]{7}{*}{1} & \multirow[t]{7}{*}{$\begin{array}{l}\text { Attraction } \\
\text { (weight }: 6 \text { ) }\end{array}$} & Landscape variation & $\begin{array}{l}\text { Mountainous landscape, Forest landscape, } \\
\text { Plantation landscape, Rice field landscape, } \\
\text { Water body (lake, river, waterfall, etc) }\end{array}$ \\
\hline & & Tourism object variation & $\begin{array}{l}\text { Natural beauty, Natural phenomenon, Water } \\
\text { body (lake, river, waterfall, etc), Cultural } \\
\text { attraction, History }\end{array}$ \\
\hline & & Tourism activity type & $\begin{array}{l}\text { Tracking/ hiking, Religius tourism, Tubing, } \\
\text { Camping, Education/ research, Enjoying } \\
\text { scenery, Photography, Viewing cultural/ } \\
\text { historical attraction, Fishing }\end{array}$ \\
\hline & & Location cleanliness & $\begin{array}{l}\text { Natural factor, Industrial factor, } \\
\text { Transportation, Settlements, Garbage, } \\
\text { Graffiti }\end{array}$ \\
\hline & & Disaster safeness area & $\begin{array}{l}\text { Landslide, Flash floods, Earthquakes, } \\
\text { Mountain eruption, Fires }\end{array}$ \\
\hline & & Slope variation & $\begin{array}{l}45 \% \text { (very steep), } 25-45 \% \text { (steep), } 15-25 \% \\
\text { (wavy), } 8-15 \% \text { (rather flat), } 0-8 \% \text { (flat) }\end{array}$ \\
\hline & & Contour variation & $\begin{array}{l}>2.000 \mathrm{~m} \text { asl, } 1.000-2.000 \mathrm{~m} \text { as } 1,500- \\
1.000 \mathrm{~m} \text { as } 1,100-500 \mathrm{~m} \text { asl, } 15-100 \mathrm{~m} \text { asl }\end{array}$ \\
\hline \multirow[t]{3}{*}{2} & \multirow{3}{*}{$\begin{array}{l}\text { Accessibility } \\
\text { (weight }: 5 \text { ) }\end{array}$} & $\begin{array}{l}\text { Estimated distance of tourism potency to the } \\
\text { district center }\end{array}$ & $\begin{array}{l}\text { 0-30 km (Ring 1), 30-70 km (Ring 2), 70-100 } \\
\mathrm{km} \text { (Ring 3), >100 (Ring 4) }\end{array}$ \\
\hline & & $\begin{array}{l}\text { Estimated distance of tourism potency to the } \\
\text { provinc ial capital }\end{array}$ & $\begin{array}{l}0-30 \mathrm{~km} \text { (Ring 1), 30-70 km (Ring 2), 70-100 } \\
\mathrm{km} \text { (Ring 3), >100 (Ring 4) }\end{array}$ \\
\hline & & $\begin{array}{l}\text { Estimated distance of tourism potency to the } \\
\text { nearest nearby tourist attraction }\end{array}$ & $\begin{array}{l}0-30 \mathrm{~km} \text { (Ring 1), 30-70 km (Ring 2), 70-100 } \\
\mathrm{km} \text { (Ring 3), >100 (Ring 4) }\end{array}$ \\
\hline \multirow[t]{2}{*}{3} & \multirow[t]{2}{*}{$\begin{array}{l}\text { Amenity } \\
\text { (weight : 3) }\end{array}$} & Supporting facilities & $\begin{array}{l}\text { Accommodation, Restaurant, Transportation, } \\
\text { Souvenir shop, Worship facilities, Banking } \\
\text { facilities, Healthcare facilities }\end{array}$ \\
\hline & & Infrastructures & $\begin{array}{l}\text { Street, Bridge, Parking area, Electric } \\
\text { network, Telecommunication network, Water } \\
\text { supply network }\end{array}$ \\
\hline
\end{tabular}

\section{Research Method}

The location of this study is in Kendal Regency especially in the mountainous areas of Plantungan, Pageruyung, Sukorejo, Patean, Singorojo, Boja, and Limbangan. Below is the location of the study:

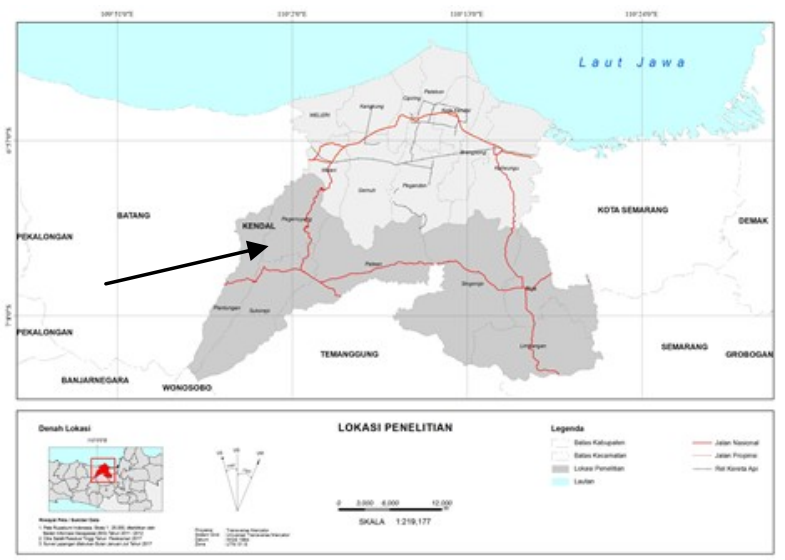

Fig. 1. Study location.
A modified method of Rahayuningsih, et.al. [4] using ADO-ODTWA (Operational Area Analysis Nature based Tourism Object and Attraction) Guidelines [6] will be used in this study. The result of ADO-ODTWA assessment then would be integrated with Geographic Information System (GIS) by tabulating it into the database of Arc Map 10.3.

The phase of this study includes preliminary study in order to find criteria of resources assessment, data collection, and data analysis, which is presented in Fig.2.

\subsection{Preliminary study}

Literature study is the first step to obtain general illustration of the study location as administrative map with the geography and demography conditions. It is carried out by collecting and reviewing data of the study locations. It is also used to determine the assessment criteria of the study [4]. 


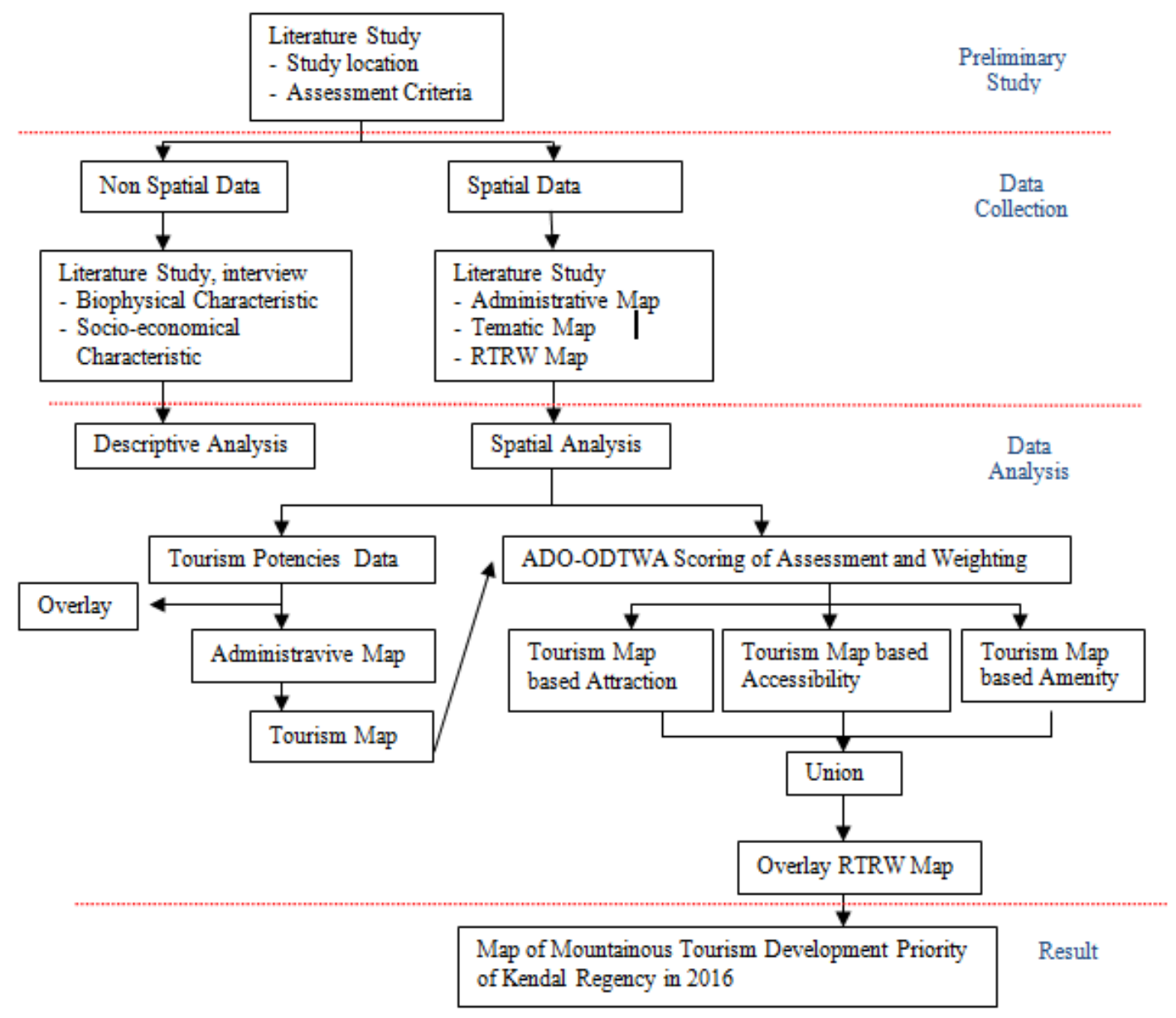

Fig. 2. Phase of Preliminary Study.

Spatial data analysis was the main analysis in this

\subsection{Data collection}

Data collection phase needs a technique related with the process of data extracting. Data must be relevant with study needs and data resources [4] includes biophysical and socio-economic characteristics of the community. Stages of data collection conducted in this study include literature study and interview.

\subsubsection{Literature study}

Data from literature studies are often referred to as secondary data. Data for this article was obtained from the library of Postgraduate Program of Diponegoro University of Semarang, Kendal District Library; Youth, Sports and Tourism Department of Kendal Regency, and other institutions related to this research.

\subsubsection{Interview}

In this study, interviews were conducted with 2 (two) officers from the tourism division of the Youth, Sports and Tourism Office of Kendal Regency.

\subsection{Data analysis}

Data analysis technique is continuously done from the beginning when the data are started to be intensively collected until the research is finished. research to produce map of the priority area of mountainous tourism in Kendal Regency in 2016, for the development of priority areas in 2017 . The first step was to assess the tourism potency using ADO-ODTWA (Operational Area Analysis - Nature based Tourism Object and Attraction) Guidelines used by Rahayuningsih, et. al [4] modified with the Strategic Plan of Tourism Ministry of Republic Indonesia 20152019 on tourism product development strategy embodied in " $3 \mathrm{~A}$ ", namely Attraction, Accessibility and Amenity. The criteria is shown in the Table 1.

The attraction criteria consisted of seven elements, $i$. e. landscape variation based on land cover, tourism object variation, tourism activities type, location cleanliness, disaster safeness area, slope and contour variation. The weight of attraction criteria is 6 , the highest number because the attraction is the main capital that allows the visitors arrival.

Accessibility criteria consisted of three elements, i.e. the estimated distance of tourism potency to the district center, the provincial capital and the nearest nearby tourist attraction, with the weight of the assessment was 5. While the criteria of amenity consisted of 2 elements, i.e. supporting facilities and infrastructure of tourism activities by rating of weight was 3 .

Scores of assessment of each criterion would be calculated using the following formula : 


$$
\mathrm{S}=\Sigma(\text { criteria value } \mathrm{x} \text { weight })
$$

While classification of each tourism objects and attractions also would be calculated using the formula :

$$
\mathrm{K}=(\mathrm{Nt}-\mathrm{Nr}): 3)
$$

$\mathrm{Nt}=$ highest value and $\mathrm{Nr}=$ lowest value. The final assessment classification would be categorized into low, medium and high, on certain intervals (Table 2). The purpose of this assessment was to obtain description of tourism potency that should be put in high priority for the development [4].

Table 2. Classification of assessment.

\begin{tabular}{|c|l|c|c|c|}
\hline \multirow{2}{*}{ No } & \multirow{2}{*}{ Criteria } & \multicolumn{3}{|c|}{ Assessment Classification } \\
\cline { 3 - 5 } & & Low & Med & High \\
\hline 1 & Attraction & $42-448$ & $449-854$ & $855-1260$ \\
\hline 2 & Accessibility & $300-600$ & $601-900$ & $901-1200$ \\
\hline 3 & Amenity & $6-64$ & $65-122$ & $123-180$ \\
\hline
\end{tabular}

The next analysis used GIS as a tool of analysis. First step was to compose basic map of distribution of mountainous tourism obtained from overlay between the administrative map with the data of tourism potency. After that, integrated the result of ADO-ODTWA assessment into Arc Map 10.3 by using tabular data. The final spatial analysis was to overlay the result of integrated tabulation and map with tourism development area of Kendal Regency so it will produce the priority of mountainous tourism development map of Kendal Regency.

\section{Results}

\subsection{ADO-ODTWA assessment of mountainous tourism potency}

ADO-ODTWA is an instrument to obtain the suitability of a certain tourism potency to be developed as naturebased tourism objects and attractions. Criteria functions as the basis in planning the development of tourism potencies, by establishing the elements of criteria, weight and calculation of each sub elements [6,7].

By using the 2016 secondary data from Youth, Sports and Tourism Department of Kendal Regency, the assessment of mountainous tourism was conducted. The result of the assessment can be seen in the Table 3 as the result of attraction assessment, Table 4 as the result of accessibility assessment and Table 5 as the result of amenity assessment in 2016 .

Based on the assessment classification (Table 2), there were 2 (two) classes of mountainous tourism potency in Kendal Regency in the criteria of attraction, accessibility and amenity, i.e. medium and high classes.

Table 3. Score of attraction assessment in $\mathbf{2 0 1 6}$

\begin{tabular}{|c|l|c|c|c|c|c|c|c|c|}
\hline No & \multicolumn{1}{|c|}{ Tourism Potency } & $\begin{array}{c}\text { Landscap } \\
\mathbf{e} \\
\text { Variation }\end{array}$ & $\begin{array}{c}\text { Tourism } \\
\text { Object } \\
\text { Variatio } \\
\mathbf{n}\end{array}$ & $\begin{array}{c}\text { Tourism } \\
\text { Activity } \\
\text { Type }\end{array}$ & $\begin{array}{c}\text { Location } \\
\text { Cleanlines } \\
\mathbf{s}\end{array}$ & $\begin{array}{c}\text { Disaster } \\
\text { Safeness } \\
\text { Area }\end{array}$ & $\begin{array}{c}\text { Slope } \\
\text { Variatio } \\
\text { n }\end{array}$ & $\begin{array}{c}\text { Coun- } \\
\text { tour } \\
\text { Variatio } \\
\text { n }\end{array}$ & $\begin{array}{c}\text { Scores } \\
\text { Total }\end{array}$ \\
\hline 1 & Agrowisata Plantera & 20 & 15 & 20 & 20 & 25 & 25 & 10 & 810 \\
\hline 2 & Dewi Selo Arjuno & 30 & 15 & 15 & 15 & 25 & 25 & 15 & 840 \\
\hline 3 & Dewi Blumah & 30 & 20 & 20 & 15 & 25 & 20 & 15 & 870 \\
\hline 4 & Dewi Bendosari & 30 & 20 & 20 & 15 & 25 & 20 & 10 & 840 \\
\hline 5 & Curug Terong & 30 & 15 & 15 & 15 & 25 & 15 & 15 & 780 \\
\hline 6 & Curugsewu & 25 & 30 & 20 & 15 & 25 & 20 & 10 & 870 \\
\hline 7 & Dewi Cacaban & 30 & 25 & 20 & 15 & 25 & 25 & 10 & 900 \\
\hline 8 & Dewi Gondang & 30 & 30 & 25 & 15 & 25 & 20 & 15 & 960 \\
\hline 9 & Dewi Ngesrepbalong & 30 & 20 & 20 & 15 & 25 & 15 & 15 & 840 \\
\hline 10 & Dewi Cening & 25 & 20 & 15 & 15 & 25 & 15 & 20 & 810 \\
\hline 11 & $\begin{array}{l}\text { Dewi Sembrani/ } \\
\text { Santosa Sable }\end{array}$ & 30 & 25 & 25 & 20 & 25 & 20 & 15 & 960 \\
\hline 12 & Dewi Peron & 30 & 30 & 20 & 15 & 25 & 20 & 20 & 960 \\
\hline 13 & Kebun Cengkeh & 30 & 15 & 15 & 25 & 25 & 15 & 15 & 840 \\
\hline 14 & Kanaran & 25 & 10 & 20 & 20 & 25 & 20 & 15 & 810 \\
\hline 15 & $\begin{array}{l}\text { Pemand Teh Medini } \\
\text { Gonoharjo }\end{array}$ & 25 & 20 & 20 & 20 & 20 & 20 & 20 & 870 \\
\hline 16 & River Tubing Genting & 25 & 20 & 20 & 15 & 25 & 20 & 15 & 840 \\
\hline
\end{tabular}


Table 4. Score of accessibility assessment in $\mathbf{2 0 1 6}$

\begin{tabular}{|c|l|c|c|c|c|}
\hline No & Tourism Potency & $\begin{array}{c}\text { Estimated distance of } \\
\text { tourism potency to } \\
\text { the district center }\end{array}$ & $\begin{array}{c}\text { Estimated distance } \\
\text { of tourism potency } \\
\text { to the provincial } \\
\text { capital }\end{array}$ & $\begin{array}{c}\text { Estimated distance of tourism } \\
\text { potency to the nearest nearby } \\
\text { tourist attraction }\end{array}$ & $\begin{array}{c}\text { Scores } \\
\text { Total }\end{array}$ \\
\hline 1 & Agrowisata Plantera & 60 & 60 & 60 & 900 \\
\hline 2 & Dewi Selo Arjuno & 60 & 60 & 60 & 900 \\
\hline 3 & Dewi Blumah & 60 & 40 & 60 & 800 \\
\hline 4 & Dewi Bendosari & 60 & 40 & 60 & 800 \\
\hline 5 & Curug Terong & 60 & 40 & 60 & 800 \\
\hline 6 & Curugsewu & 60 & 60 & 60 & 900 \\
\hline 7 & Dewi Cacaban & 60 & 60 & 60 & 900 \\
\hline 8 & Dewi Gondang & 60 & 60 & 60 & 900 \\
\hline 9 & Dewi Ngesrepbalong & 60 & 60 & 60 & 900 \\
\hline 10 & Dewi Cening & 60 & 60 & 60 & 900 \\
\hline 11 & Dewi Sembrani/ Santosa & 60 & 80 & 80 & 1100 \\
\hline 12 & Dable & 60 & 60 & 60 & 900 \\
\hline 13 & Kebun Cengkeh & 60 & 40 & 60 & 800 \\
\hline 14 & Kebun Teh Medini & 60 & 60 & 60 & 90 \\
\hline 15 & $\begin{array}{l}\text { Pemandian Air Panas } \\
\text { Gonoharjo }\end{array}$ & 60 & 60 & 600 & 9 \\
\hline 16 & River Tubing Genting & 60 & & & 9 \\
\hline
\end{tabular}

Table 5. Score of amenity assessment in 2016

\begin{tabular}{|c|l|c|c|c|}
\hline No & \multicolumn{1}{|c|}{ Tourism Potency } & $\begin{array}{c}\text { Supporting } \\
\text { facilities }\end{array}$ & $\begin{array}{c}\text { Infrastructure } \\
\text { s }\end{array}$ & Scores Total \\
\hline 1 & Agrowisata Plantera & 20 & 30 & 150 \\
\hline 2 & Dewi Selo Arjuno & 15 & 20 & 105 \\
\hline 3 & Dewi Blumah & 15 & 25 & 120 \\
\hline 4 & Dewi Bendosari & 15 & 25 & 120 \\
\hline 5 & Curug Terong & 15 & 15 & 90 \\
\hline 6 & Curugsewu & 25 & 30 & 165 \\
\hline 7 & Dewi Cacaban & 20 & 25 & 135 \\
\hline 8 & Dewi Gondang & 20 & 25 & 135 \\
\hline 9 & Dewi Ngesrepbalong & 15 & 25 & 120 \\
\hline 10 & Dewi Cening & 20 & 20 & 105 \\
\hline 11 & Dewi Sembrani/ Santosa Sable & 15 & 30 & 150 \\
\hline 12 & Dewi Peron & 15 & 25 & 120 \\
\hline 13 & Kebun Cengkeh Banaran & 15 & 25 & 120 \\
\hline 14 & Kebun Teh Medini & 15 & 30 & 120 \\
\hline 15 & Pemand ian Air Panas Gonoharjo & 15 & 20 & 135 \\
\hline 16 & River Tubing Genting & & 105 \\
\hline
\end{tabular}

\subsection{GIS analysis result}

The first step done in GIS analysis was to compose basic map of distribution of mountainous tourism by overlaying between the administrative map with the data of tourism potency. Score of each elements of ADOODTWA assessment was then integrated into Arc Map 10.3 by tabulating them. It would resulted in 3 (three) thematic maps, i.e. Tourism Map based on Attraction (Fig. 3), Tourism Map based on Accessibility (Fig. 4) and Tourism Map based on Amenity (Fig. 5). 


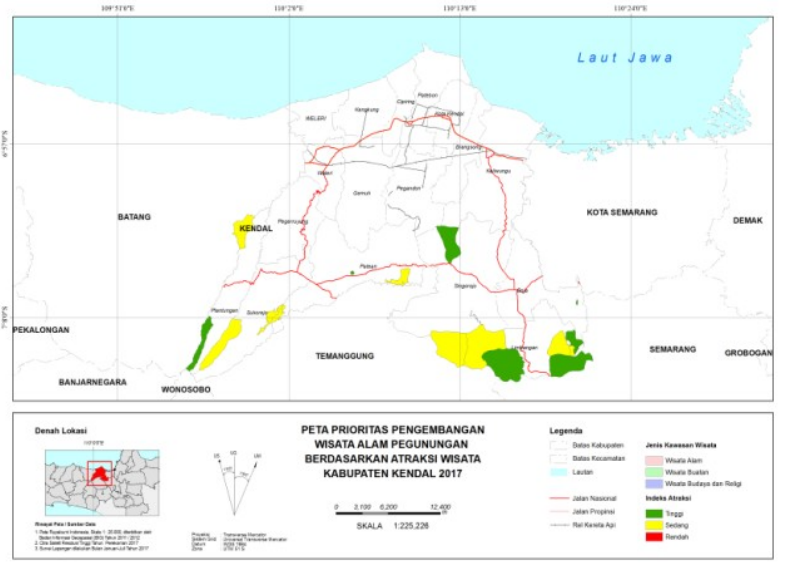

Fig. 3. Tourism map based on attraction in 2016

From Fig.3, it can be seen that there were 8 (eight) tourism potencies in 2016 which were then classified into 'high priority' based on attraction criteria, such Dewi Blumah, Curugsewu, Dewi Cacaban, Dewi Peron, Dewi Gondang, Kebun Teh Medini, Pemandian Air Panas Gonoharjo and Dewi Sembrani/ Santosa Stable. The other eight are belonged to 'middle priority' including Dewi Bendosari, Curug Terong, Kebun Cengkeh Banaran, Agrowisata Plantera, River Tubing Genting, Dewi Selo Arjuno, Dewi Cening, and Dewi Ngesrepbalong.

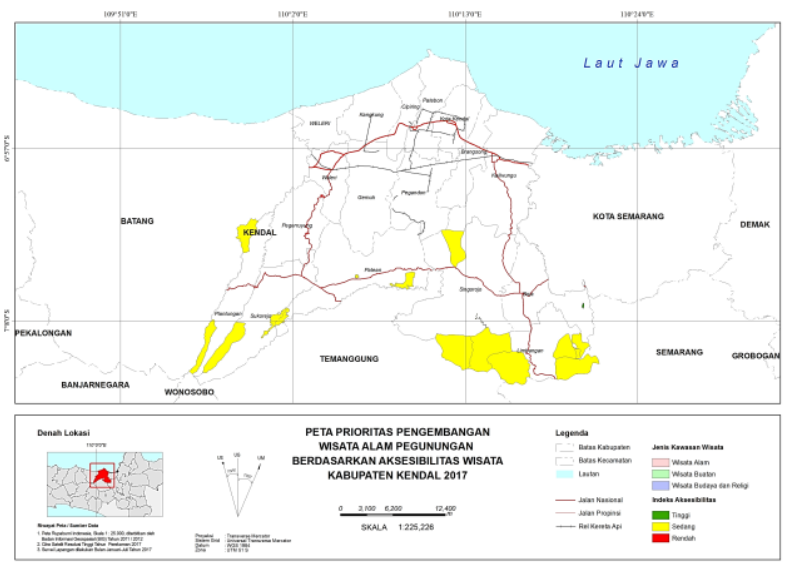

Fig. 4. Tourism map based on accessibility in 2016

While in Fig 4, almost all of the tourism potencies are included into 'middle priority' based on accessibility criteria, except Dewi Sembrani/ Santosa Stable. It is because the location of Dewi Sembrani/ Santosa Stable is near to the provincial capital of Central Java and also near to the nearest nearby tourist attraction.

Same as Fig 4, Fig 5 also shows that mostly of tourism potencies are included into 'middle priority' based on accessibility criteria, except Dewi Sembrani/ Santosa Stable that has more complete supporting facilities and infrastructures than others.

The final step did in spatial analysis was to overlay both of those thematic maps (tourism map based on attraction, accessibility, and amenity) with the map of tourism area development on spatial planning of Kendal Regency. So it would result the map of mountainous tourism development priority of Kendal Regency as shown on Fig. 6 below.

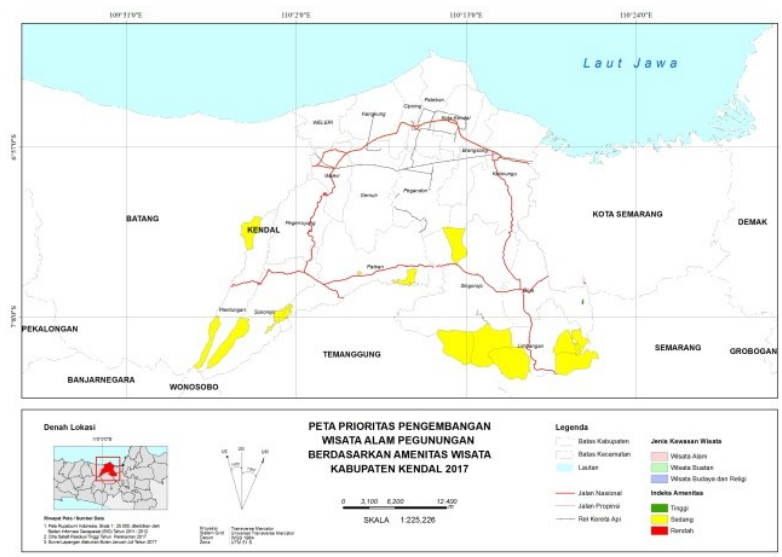

Fig. 5. Tourism map based on amenity in 2016

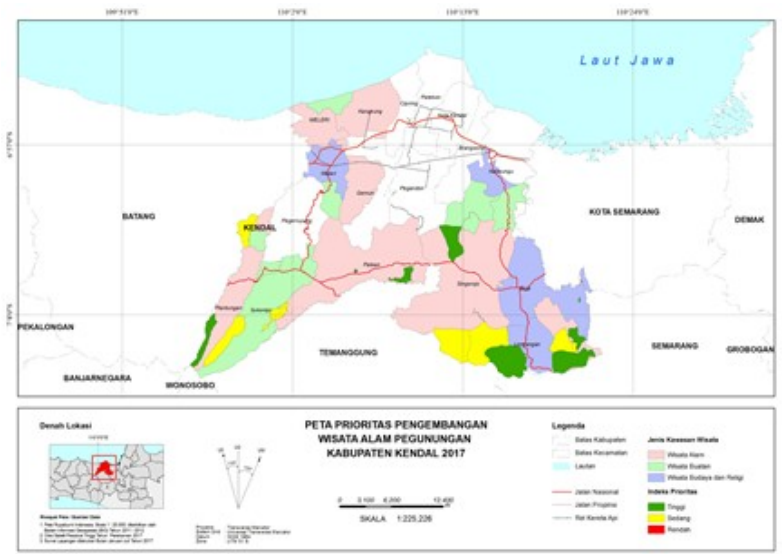

Fig. 6. Map of mountainous tourism development priority of Kendal Regency in 2016

\section{Conclusion}

The final result showed that there were 7 (seven) tourism potencies than could be prioritized as a mountainous tourism development in 2016, i.e. (1) Dewi Blumah in the Plantungan District, (2) Curugsewu and (3) Agrowisata Plantera in Patean District, (4) Dewi Cacaban in Singoojo District, (5) Dewi Gondang, (6) Pemandian Air Panas Gonoharjo and (7) Kebun Teh Medini in Limbangan District.

Eventhough Dewi Sembrani/ Santosa Stable was categorized into high priority in all criteria, it could not become a priority in the mountainous tourism development area because it was not included in the area of nature tourism development but rather in the cultural tourism development in the spatial planning of Kendal Regency.

Therefore, this result can be used as a guidance to determine the further priority area of mountainous tourism development in Kendal Regency, such as in 2017. 


\section{References}

1. Kabupaten Kendal, B.P.S.K, Kabupaten Kendal Dalam Angka 2015, Kendal: Badan Pusat Statistik Kabupaten Kendal, (2015).

2. Sunardiono, Upaya Pengembangan Obyek Wisata Gonoharjo Kecamatan Limbangan Kabupaten Kendal, Skripsi, Universitas Negeri Semarang (2009)

3. S. Yuliadi, Analisis Potensi Pengembangan Obyek Wisata Alam di Kabupaten Kendal, Skripsi, Universitas Muhammadiyah Surakarta, (2011

4. T.Rahayuningsih, E.K.S.H. Muntasib ,\& L. Budi, J.Proenv, 33, 365-375, (2016)

5. JM. Tambunan, S. Anggoro \& H. Purnaweni, Proceeding of National Conference on Natural Resources and Environment Management. Kajian Kualitas Lingkungan dan Kesesuaian Wisata Pantai Tanjung Pesona Kabupaten Bangka, 356-362. (2013)

6. Perlindungan Hutan dan Konservasi Alam (PHKA), Pedoman Analisis Daerah Operasi Obyek dan Daya Tarik Wisata Alam (ADO-ODTWA), Bogor: Direktorat Jenderal Perlindungan Hutan dan Konservasi Alam, (2003)

7. P. Oktadiyani, Alternatif Strategi Pengelolaan Taman Wisata Alam Kawah Kamojang Kabupaten Bandung Provinsi Jawa Barat, Bandung: Institut Pertanian Bogor, (n.d),

8. J.S. Muin and R.S. Wulandari, Penilaian Daya Tarik dan Pengembangan Obyek Wisata Pantai
Tanjung Belandang di Kabupaten Ketapang, Pontianak : Universitas Tanjungpura, (n.d).

9. K. Bunruamkaew \& Y. Murayama, J.Sbspro, 21, 269-278, (2011)

10. G. Hai-Ling, et.al. J.Proeng, 15,1988-1992, (2011)

11. Departemen Kebudayaan dan Pariwisata, UndangUndang Republik Indonesia No. 10 Tentang Kepariwisataan.

12. H. Marpaung, Pengetahuan Kepariwisataan. Bandung : Alfabeta, (2000)

13. R.G. Soekadijo, Anatomi Pariwisata.Jakarta: PT. Gramedia Pustaka Utama, (2000)

14. P.A. Burrough, Principles of GIS for Land Resources Survey, New York: Oxford Science Publications, (1986)

15. S. Aronoff, A Review of Geographic Information System : A Management Perspective, Ottawa : WDL Publication, Pp. 294, (1989)

16. NR. Chrisman, ExploringGeographic Information System, John wilwy, 298 pp (first Ed), (1997)

17. H. Purnaweni, Proceeding of International Annual Conference of Public Policy, Intensive Use of Geographic Information System for Public Policy, 134-141. Malang : University of Brawijaya, (2012)

18. Kementrian Pariwisata, Rencana Strategis: Pengembangan Destinasi dan Industri Pariwisata Kementrian Pariwisata Tahun 2015-2019, Jakarta : Deputi Bidang Pengembangan Destinasi dan Industri Pariwisata Kementrian Pariwisata, (2015). 